\title{
Caking And Degradation Problem on Nitrogenous Fertiliser and Alternative Solution Processes
}

\author{
Ahmet Ozan Gezerman (Corresponding Author) \\ Yildiz Technical University, Chemical-Metallurgical Faculty \\ Chemical Engineering Department, Istanbul, Turkey \\ Tel: 90-532-653-8505 E-mail: ahmet_ozan@yahoo.com \\ Burcu Didem Corbacioglu \\ Yildiz Technical University, Chemical-Metallurgical Faculty \\ Chemical Engineering Deparment, Istanbul, Turkey
}

Received: January 20, 2011 Accepted: February 14, 2011 doi:10.5539/ijc.v3n3p123

\begin{abstract}
Toward the end of the 1950s, the development of new techniques to improve the yields from available agricultural areas has become essential to meet food requirements owing to the rapidly increasing world population. Therefore, new strategies have been determined to increase product quality in industries that serve agricultural areas.

In this study, we attempted to minimise unwanted reactions involved in the manufacturing process of chemical fertilisers.

Keywords: Nitrogenous fertilisers, Caking problem, Degradation problem, Double salts

\section{Introduction}

Most of the granular and prilled fertiliser that contains sulphates and nitrates is produced in Europe, Japan, and the USA. After production, some of these products degrade whereas other products suffer caking problems. In this study, prilled fertiliser that has been produced in Turkey was tested and the causes of caking and degradation problems in $\left(\mathrm{NH}_{4}, \mathrm{Mg}\right)_{4}\left(\mathrm{NO}_{3}\right)_{2} \mathrm{SO}_{4}$ double salts, called B, were determined. $\mathrm{NH}_{4} \mathrm{NO}_{3}-\left(\mathrm{NH}_{4}\right)_{2} \mathrm{SO}_{4}$, $\mathrm{NH}_{4} \mathrm{NO}_{3}-\mathrm{Mg}\left(\mathrm{NO}_{3}\right)_{2}$ and $\mathrm{NH}_{4} \mathrm{NO}_{3}-\mathrm{Mg}\left(\mathrm{NO}_{3}\right)_{2}-\mathrm{MgSO}_{4}-\left(\mathrm{NH}_{4}\right)_{2} \mathrm{SO}_{4}$ solutions were prepared and the phase change and volume change in heat were analysed as the main focus area for the caking and degradation problem.
\end{abstract}

\section{Testing of prilled fertilisers}

Previous studies have revealed that 26\% nitrogenous fertiliser (CAN-calcium ammonium nitrate), $33 \%$ nitrogenous fertiliser (AN-ammonium nitrate) and 35\% nitrogenous fertiliser $\left(\mathrm{AN}-\mathrm{Mg}\left(\mathrm{NO}_{3}\right)_{2}\right)$ are used most often in the manufacture of nitrogenous fertiliser. Furthermore, 26\% nitrogenous fertiliser (CAN) and 33\% nitrogenous fertiliser (AN) have been produced by prilling: drying at $100{ }^{\circ} \mathrm{C}$; reacting at $170{ }^{\circ} \mathrm{C}$ with $0.3 \%$ moisture; followed by the addition of $\mathrm{HNO}_{3}, \mathrm{NH}_{3}$, and $\mathrm{CaCO}_{3}$ (Ando, Siegal \& Jordan, 1965, pp. 13). The 26\% nitrogenous fertiliser tends to cake whereas $33 \%$ nitrogenous fertiliser tends to degrade (Ando, Miyamura \& Akiyama, 1967). In addition $35 \% \mathrm{AN}$ is made by mixing ammonium nitrate and magnesium nitrate $\left(\mathrm{Mg}\left(\mathrm{NO}_{3}\right)_{2}\right)$ and prilling the solution. This product tends to degrade slowly when stored (Ando \& Sai, 1970, pp. 2614). The $26 \%$ CAN contains $0.3 \%$ moisture whereas the $33 \%$ AN and magnesium nitrate $\left(\mathrm{Mg}\left(\mathrm{NO}_{3}\right)_{2}\right)$ contain $0.5 \%$ moisture. Here, determinations of the whole chemical compounds that result from the reactions were conducted using a Shimadzu GC-MS, model of a QP 5050A mass spectrometer.

$\mathrm{X}$ ray results of tested fertilisers are shown in Table 1. X-ray analyses were conducted using "Fischer Instruments $\mathrm{GmbH}, 2002$ ” X-ray equipment. X-ray analyses were conducted a few weeks after production.

\subsection{Ammonium nitrate-Ammonium sulphate system in the manufacture of nitrogenous fertiliser}

Previous studies have indicated that there are two double salts, $3 \mathrm{NH}_{4} \mathrm{NO}_{3} \cdot\left(\mathrm{NH}_{4}\right)_{2} \mathrm{SO}_{4}$ (A) and $2 \mathrm{NH}_{4} \mathrm{NO}_{3} \cdot\left(\mathrm{NH}_{4}\right)_{2} \mathrm{SO}_{2}$ (B), present in this system (Theoret, A., \& Sandorfy., 1963, pp. 57-61). However, this does 
account for the thermal change of this system. In this paper, Figure 6 shows a phase diagram related to this system.

$\mathrm{H}_{2} \mathrm{SO}_{4}$ is used in the production of nitrogenous fertiliser to effectively change ammonium nitrate. If the amount of $\mathrm{SO}_{4}$ exceeds $0.3 \%$, ammonium nitrate (III) (orthorhombic) will not form. Therefore, ammonium nitrate (IV)(ortorhombic) is formed at $51{ }^{\circ} \mathrm{C}$. The temperature required to change it from form II (tetragonal) to form I (cubic) decreases from $125{ }^{\circ} \mathrm{C}$ to $107{ }^{\circ} \mathrm{C}$. The melting point of ammonium nitrate increases from $169{ }^{\circ} \mathrm{C}$ to $181{ }^{\circ} \mathrm{C}$ upon the addition of $0.5 \% \mathrm{H}_{2} \mathrm{SO}_{4}$.

If the amount of $\mathrm{H}_{2} \mathrm{SO}_{4}$ exceeds $0.5 \%$, the melting point increases markedly (Coats \& Woodard, 1965, pp. 2135). Therefore, ammonium sulphate first crystallises from the solution upon cooling (Yanagi, 1965, pp. 1351). After further cooling, form I (cubic) crystallised at $181{ }^{\circ} \mathrm{C}$ (Levin, 1969, pp. 264). The solution contained $3 \mathrm{NH}_{4} \mathrm{NO}_{3}$. $\left(\mathrm{NH}_{4}\right)_{2} \mathrm{SO}_{4}(\mathrm{~A})$ at $162{ }^{\circ} \mathrm{C}$.

When the mixture of $\mathrm{AN}$ and $\mathrm{H}_{2} \mathrm{SO}_{4}$ was heated, the product formed was a solution of $3 \mathrm{NH}_{4} \mathrm{NO}_{3} \cdot\left(\mathrm{NH}_{4}\right)_{2} \mathrm{SO}_{4}(\mathrm{~A})$ and $\left(\mathrm{NH}_{4}\right)_{2} \mathrm{SO}_{4}$. When this solution cooled to room temperature, it changed to $2 \mathrm{NH}_{4} \mathrm{NO}_{3} \cdot\left(\mathrm{NH}_{4}\right)_{2} \mathrm{SO}_{2}(\mathrm{~B})$. The presence of moisture accelerates this reaction. When $2 \mathrm{NH}_{4} \mathrm{NO}_{3} \cdot\left(\mathrm{NH}_{4}\right)_{2} \mathrm{SO}_{2}(\mathrm{~B})$ is heated to $160{ }^{\circ} \mathrm{C}$, it decomposes into $3 \mathrm{NH}_{4} \mathrm{NO}_{3} \cdot\left(\mathrm{NH}_{4}\right)_{2} \mathrm{SO}_{4}(\mathrm{~A})$ and $\left(\mathrm{NH}_{4}\right)_{2} \mathrm{SO}_{4}$, its constituent molecules. This decomposition is also observed if the moisture content is low.

\section{$2.2 \mathrm{NH}_{4} \mathrm{NO}_{3}-\mathrm{Mg}\left(\mathrm{NO}_{3}\right)_{2}$ system}

The phase diagram for this system is shown in Figure 7. A small amount of $\mathrm{Mg}\left(\mathrm{NO}_{3}\right)_{2}$ has allowed form III (orthorhombic) of $\mathrm{AN}$ to be stable through a wide temperature range. At room temperature, a part of the $25 \%$ $\mathrm{NH}_{3}$ in the form of $\mathrm{AN}$, can replace the magnesium. $\mathrm{NH}_{4} \mathrm{NO}_{3} \cdot 2 \mathrm{Mg}\left(\mathrm{NO}_{3}\right)_{2}(\mathrm{C})$, a double salt, is formed when the amount of magnesium increases to $25 \%$. This is shown in reaction (1).

The stabilised forms of pure $\mathrm{Mg}\left(\mathrm{NO}_{3}\right)_{2}$ assume form I and form II (tetragonal) below and above $130{ }^{\circ} \mathrm{C}$, respectively. From experiments conducted to observe the effect of temperature on the forms of $\mathrm{Mg}\left(\mathrm{NO}_{3}\right)_{2}$, we observed that pure $\mathrm{Mg}\left(\mathrm{NO}_{3}\right)_{2}$ and form III (II') of $\mathrm{Mg}\left(\mathrm{NO}_{3}\right)_{2}$ occur at $126{ }^{\circ} \mathrm{C}$ upon cooling. Using conducting tests, we demonstrated that $\mathrm{NH}_{4} \mathrm{NO}_{3} \cdot 2 \mathrm{Mg}\left(\mathrm{NO}_{3}\right)_{2}(\mathrm{C})$ and III'(orthorhombic) have similar forms. At about $120{ }^{\circ} \mathrm{C}$ these chemicals yield 87 moles of $\mathrm{AN}$ and 13 moles of $\mathrm{Mg}\left(\mathrm{NO}_{3}\right)_{2}$. After cooling, according to the composition of $\mathrm{NH}_{4} \mathrm{NO}_{3} \cdot 2 \mathrm{Mg}\left(\mathrm{NO}_{3}\right)_{2}(\mathrm{C})$ and solid solution, ammonium nitrate (form III-orthorhombic) and $\mathrm{Mg}\left(\mathrm{NO}_{3}\right)_{2}(\mathrm{II}$ ') (tetragonal) can be separated stoichiometrically.

\section{$2.3 \mathrm{NH}_{4} \mathrm{NO}_{3}-\mathrm{Mg}\left(\mathrm{NO}_{3}\right)_{2}-\mathrm{MgSO}_{4^{-}}\left(\mathrm{NH}_{4}\right)_{2} \mathrm{SO}_{4}$ system}

A phase diagram is obtained after testing the solution below $180{ }^{\circ} \mathrm{C}$ as shown in Figure 1 . Testing above $180{ }^{\circ} \mathrm{C}$ has not yielded reliable results because $\mathrm{AN}$ degrades. Conduction tests revealed that $2 \mathrm{NH}_{4} \mathrm{NO}_{3} \cdot \mathrm{Mg}\left(\mathrm{NO}_{3}\right)_{2}$ first crystallised in the melt that was rich in $\mathrm{NH}_{4} \mathrm{NO}_{3}$ and $\mathrm{Mg}\left(\mathrm{NO}_{3}\right)_{2}$. However, it might not be possible to obtain these salts all the time. For $\mathrm{X}<0.05$ and $\mathrm{Y}>0.15, \mathrm{Mg}\left(\mathrm{NO}_{3}\right)_{2}$ form $\mathrm{I}(\mathrm{I}$ ') (cubic) crystallized first in the melt and then changed to a $\mathrm{NH}_{4} \mathrm{NO}_{3} \cdot 2 \mathrm{Mg}\left(\mathrm{NO}_{3}\right)_{2}(\mathrm{C})$ solution with two moles of $\mathrm{NH}_{4} \mathrm{NO}_{3}$ and one mole of $\mathrm{Mg}\left(\mathrm{NO}_{3}\right)_{2}$ (reaction (2)). If the rate of $\mathrm{X}\left(\mathrm{SO}_{4} / \mathrm{NO}_{3}+\mathrm{SO}_{4}\right)$ is larger than 0.05 , the melting point increases markedly and the first crystallised material will be $\left(\mathrm{NH}_{4}, \mathrm{Mg}\right) \mathrm{SO}_{4}$ in the melt.

In another test, various mixtures of the system were heated to $160{ }^{\circ} \mathrm{C}$, kept at $150{ }^{\circ} \mathrm{C}$ for 1 hour, and then cooled to room temperature. A- $\left(\mathrm{NH}_{4}\right)_{2} \mathrm{SO}_{4}$ only occurred when $\mathrm{Y}\left(\mathrm{Mg} / \mathrm{NH}_{4}+\mathrm{Mg}\right)$ was smaller than 0.1 . When the rate of $\left(\mathrm{Mg} / \mathrm{NH}_{4}+\mathrm{Mg}\right)$ was smaller than $0.1,2 \mathrm{NH}_{4} \mathrm{NO}_{3} \cdot\left(\mathrm{NH}_{4}\right)_{2} \mathrm{SO}_{2}(\mathrm{~B})$ and form III (orthorhombic) of $\mathrm{NH}_{4} \mathrm{NO}_{3}$ occurred instead of A-( $\left(\mathrm{NH}_{4}\right)_{2} \mathrm{SO}_{4}$. In particular, when there was no $\mathrm{Mg}$ in $\left(\mathrm{NH}_{4}\right)_{2} \mathrm{SO}_{4}$, up to $40 \%$ of the $\mathrm{NH}_{3}$ in $2 \mathrm{NH}_{4} \mathrm{NO}_{3} \cdot\left(\mathrm{NH}_{4}\right)_{2} \mathrm{SO}_{2}(\mathrm{~B})$ was replaced with $\mathrm{Mg}$.

Figure 5 shows compounds of the above product having $0.3 \%$ moisture when the stabilised product formed. Figures 2 and 3 show that $\left(\mathrm{NH}_{4}, \mathrm{Mg}\right) \mathrm{SO}_{4}$ and $\mathrm{NH}_{4} \mathrm{NO}_{3}$ (III)(orthorhombic), which occur simultaneously, or $\mathrm{NH}_{4} \mathrm{NO}_{3} \cdot 2 \mathrm{Mg}\left(\mathrm{NO}_{3}\right)_{2}(\mathrm{C})$ changes to $2 \mathrm{NH}_{4} \mathrm{NO}_{3} \cdot\left(\mathrm{NH}_{4}\right)_{2} \mathrm{SO}_{2}(\mathrm{~B})$ at room temperature.

$$
\begin{aligned}
& 2\left(\mathrm{NH}_{4}, \mathrm{Mg}\right) \mathrm{Mg}\left(\mathrm{NO}_{3}\right)_{2}(75: 25)+\left(\mathrm{NH}_{4}, \mathrm{Mg}\right)_{2} \mathrm{SO}_{4}(75: 25) \rightarrow\left(\mathrm{NH}_{4}, \mathrm{Mg}\right)_{4}\left(\mathrm{NO}_{3}\right)_{2} \mathrm{SO}_{4}(75: 25) \ldots \ldots \ldots(1) \\
& \mathrm{NH}_{4} \mathrm{NO}_{3} \cdot 2 \mathrm{Mg}\left(\mathrm{NO}_{3}\right)_{2}+\left(\mathrm{NH}_{4}, \mathrm{Mg}\right)_{2} \mathrm{SO}_{4}+(70: 30) \rightarrow\left(\mathrm{NH}_{4}, \mathrm{Mg}\right)_{4}\left(\mathrm{NO}_{3}\right)_{2} \mathrm{SO}_{4}(60: 40)+\mathrm{Mg}\left(\mathrm{NO}_{3}\right)_{2} \ldots \ldots \ldots . . .(2)
\end{aligned}
$$

The numbers in brackets indicate atomic rates of $\mathrm{NH}_{4} / \mathrm{Mg}$ in the solid solution.

\section{Thermal behaviour of compounds}

$\mathrm{X}$-ray results at high temperature and differential temperature are shown in Figure 4.

The sample whose thermal behaviour was analysed, $2 \mathrm{NH}_{4} \mathrm{NO}_{3} \cdot\left(\mathrm{NH}_{4}\right)_{2} \mathrm{SO}_{2}$ (B), contains less $\mathrm{Mg}\left(\mathrm{NO}_{3}\right)_{2}(\mathrm{II}$ ') (tetragonal) and $\left(\mathrm{NH}_{4}, \mathrm{Mg}\right)_{2} \mathrm{SO}_{4}$. When it was heated, $\mathrm{Mg}\left(\mathrm{NO}_{3}\right)_{2}$ changed to $\mathrm{NH}_{4} \mathrm{NO}_{3} \cdot 2 \mathrm{Mg}\left(\mathrm{NO}_{3}\right)_{2}(\mathrm{C})$ solid 
solution at $110{ }^{\circ} \mathrm{C}$. Then, it changed to $\mathrm{Mg}\left(\mathrm{NO}_{3}\right)_{2}$ (I') (cubic) solid solution. At $150{ }^{\circ} \mathrm{C}, 2 \mathrm{NH}_{4} \mathrm{NO}_{3}\left(\mathrm{NH}_{4}\right)_{2} \mathrm{SO}_{2}(\mathrm{~B})$ seperated into $\left(\mathrm{NH}_{4}, \mathrm{Mg}\right)_{2} \mathrm{SO}_{4}$ and $\mathrm{Mg}\left(\mathrm{NO}_{3}\right)_{2}$ (I') (cubic). During cooling, form I' (cubic) of $\mathrm{Mg}\left(\mathrm{NO}_{3}\right)_{2}$ changed to $\mathrm{NH}_{4} \mathrm{NO}_{3} \cdot 2 \mathrm{Mg}\left(\mathrm{NO}_{3}\right)_{2}(\mathrm{C})$ solid solution at $130{ }^{\circ} \mathrm{C}$. After cooling, the compounds formed were $\mathrm{NH}_{4} \mathrm{NO}_{3} \cdot 2 \mathrm{Mg}\left(\mathrm{NO}_{3}\right)_{2}(\mathrm{C})$ and $\left(\mathrm{NH}_{4}, \mathrm{Mg}\right)_{2} \mathrm{SO}_{4}$. The mixture of $\left(\mathrm{NH}_{4}, \mathrm{Mg}\right)_{2} \mathrm{SO}_{4}$ and $\mathrm{NH}_{4} \mathrm{NO}_{3} \cdot 2 \mathrm{Mg}\left(\mathrm{NO}_{3}\right)_{2}(\mathrm{C})$ was moisturised and kept at room temperature.

In other tests, a part of $2 \mathrm{NH}_{4} \mathrm{NO}_{3} \cdot\left(\mathrm{NH}_{4}\right)_{2} \mathrm{SO}_{2}$ (B) in samples containing $2 \mathrm{NH}_{4} \mathrm{NO}_{3} \cdot\left(\mathrm{NH}_{4}\right)_{2} \mathrm{SO}_{2}$ (B) and $0.5 \%$ moisture at $80{ }^{\circ} \mathrm{C}$, decomposed into $\left(\mathrm{NH}_{4}, \mathrm{Mg}\right)_{2} \mathrm{SO}_{4}$ and $\mathrm{NH}_{4} \mathrm{NO}_{3} \cdot 2 \mathrm{Mg}\left(\mathrm{NO}_{3}\right)_{2}(\mathrm{C})$ or form III (orthorhombic) of $\mathrm{NH}_{4} \mathrm{NO}_{3}$. Decomposition was realised more easily and quickly upon reaction of $2 \mathrm{NH}_{4} \mathrm{NO}_{3} \cdot\left(\mathrm{NH}_{4}\right)_{2} \mathrm{SO}_{2}(\mathrm{~B})$ and magnesium at high rates. On the other hand, at room temperature, in the reaction by $\mathrm{Mg}$ that has a low rate, the formation of $2 \mathrm{NH}_{4} \mathrm{NO}_{3} \cdot\left(\mathrm{NH}_{4}\right)_{2} \mathrm{SO}_{2}$ (B) from $\mathrm{NH}_{4} \mathrm{NO}_{3}$ or $\left(\mathrm{NH}_{4}, \mathrm{Mg}\right)_{2} \mathrm{SO}_{4}(\mathrm{C})$ occured more easily and quickly.

\subsection{Volume change and reaction heat}

Table 2 shows that heat of formation of the solid solution and double salts was determined by measuring the heat of dissolution of the water-soluble solution. The whole reaction was endothermic. Heat absorption in $2 \mathrm{NH}_{4} \mathrm{NO}_{3} \cdot\left(\mathrm{NH}_{4}\right)_{2} \mathrm{SO}_{2}(\mathrm{~B})$ increased with $\mathrm{Mg}$.

Table 3 lists the true densities of the mixture of double salts, single salts, and solid solutions. A specific gravity vessel was used for measuring densities. For this purpose, oil was added into it along with the fine material, and the density of the simple salts and double salts were measured. If a solid solution or double salts are formed from the single salts, the volume of $2 \mathrm{NH}_{4} \mathrm{NO}_{3} \cdot\left(\mathrm{NH}_{4}\right)_{2} \mathrm{SO}_{2}$ (B) will increase considerably, without $\mathrm{Mg}$ in the reaction. Therefore, the volume will decrease with an increase in the amount of $\mathrm{Mg}$.

\subsection{Testing of the commercial products containing $2 \mathrm{NH}_{4} \mathrm{NO}_{3}\left(\mathrm{NH}_{4}\right)_{2} \mathrm{SO}_{2}(\mathrm{~B})$ at high rates}

The $26 \% \mathrm{CAN}$ and $33 \% \mathrm{AN}$ containing $2 \mathrm{NH}_{4} \mathrm{NO}_{3} \cdot\left(\mathrm{NH}_{4}\right)_{2} \mathrm{SO}_{2}$ (B) double salt was produced by reacting $\mathrm{AN}$ and $\mathrm{H}_{2} \mathrm{SO}_{4}$ at high rates. $2 \mathrm{NH}_{4} \mathrm{NO}_{3}\left(\mathrm{NH}_{4}\right)_{2} \mathrm{SO}_{2}$ (B) in $33 \% \mathrm{AN}$ contains more $\mathrm{Mg}$ than $2 \mathrm{NH}_{4} \mathrm{NO}_{3} \cdot\left(\mathrm{NH}_{4}\right)_{2} \mathrm{SO}_{2}(\mathrm{~B})$ in $26 \%$ CAN. Samples were tested by X-ray studies a few weeks after production. During this time, changes in their chemical construction were as expected. To determine the phase formed after production, $26 \%$ and $33 \%$ AN fertiliser samples with $0.5 \%$ moisture were prepared in sealed test-tubes dried at $80-100{ }^{\circ} \mathrm{C}$, and they were analysed by X-ray after they were brought to room temperature. These samples were marked as $26 \% \mathrm{CAN} / 80$, $26 \% \mathrm{CAN} / 100,33 \% \mathrm{AN} / 80$, and $33 \% \mathrm{AN} / 100$ according to their drying temperatures.

$26 \% \mathrm{CAN} / 80$ and $26 \% \mathrm{CAN} / 100$ contained much less $2 \mathrm{NH}_{4} \mathrm{NO}_{3} \cdot\left(\mathrm{NH}_{4}\right)_{2} \mathrm{SO}_{2}(\mathrm{~B})$ than they did prior to absorption of the moisture. During cooling, when the samples contained $1 \%$ moisture at room temperature, the amount of $2 \mathrm{NH}_{4} \mathrm{NO}_{3} \cdot\left(\mathrm{NH}_{4}\right)_{2} \mathrm{SO}_{2}$ (B) in $26 \% \mathrm{CAN} / 80$ and $33 \% \mathrm{AN} / 100$ increased rapidly. The composition of the product formed at this condition is similar to that of $26 \% \mathrm{CAN}$ and $33 \% \mathrm{AN}$ before moisture was added.

These results indicate that the product is similar to $26 \% \mathrm{CAN} / 80,26 \% \mathrm{CAN} / 100,33 \% \mathrm{AN} / 80$, and $33 \% \mathrm{AN} / 100$. Hence, after a few weeks of storage, they could be changed to $26 \%$ CAN and $33 \%$ AN before moistured was added.

The heat of formation of $2 \mathrm{NH}_{4} \mathrm{NO}_{3} \cdot\left(\mathrm{NH}_{4}\right)_{2} \mathrm{SO}_{2}(\mathrm{~B})$, which was produced by the above reactions, was determined by measuring the heat of dissolution of an aqueous solution of $26 \% \mathrm{CAN}, 33 \% \mathrm{AN}$, and $33 \% \mathrm{AN} / 80$. As $0.1 \mathrm{cal} / \mathrm{g}$ of heat is absorbed during the change from $\mathrm{AN} / 80$ to $\mathrm{AN}, 0.5 \mathrm{cal} / \mathrm{g}$ of heat was emitted from the reaction of $26 \%$ CAN/80 to $26 \%$ CAN. Tests were conducted using a Gallenkamp, MMF-KM-073 model calorimeter bomb. The heat of the reactions can be calculated from the data in Tables 1 and 2.

Volume changes for the reaction that changes $26 \%$ CAN/100 or $26 \%$ CAN/80 (M) to $26 \%$ CAN (N) and $33 \%$ $\mathrm{AN} / 100$ or $33 \% \mathrm{AN} / 80(\mathrm{M})$ to $33 \% \mathrm{AN}(\mathrm{N})$ have been calculated in Table 3 . The calculations show that the reaction volume increases by $3.23 \%$ for the first reaction (reaction (1)), and decreases by $1.4 \%$ for the second reaction (reaction (2)).

These results indicate a large volume change occurs with heat emission and prilled fertilisers degrade in storage to $26 \%$ AN with an increase in composition of $2 \mathrm{NH}_{4} \mathrm{NO}_{3} \cdot\left(\mathrm{NH}_{4}\right)_{2} \mathrm{SO}_{2}$ (B). $2 \mathrm{NH}_{4} \mathrm{NO}_{3} \cdot\left(\mathrm{NH}_{4}\right)_{2} \mathrm{SO}_{2}$ (B) on the surface of prilled AN forms a white blister (Figure 5). Moisture on the surface of the prilled fertiliser is lost on drying. However, the reduced amount of moisture changes the shape of $2 \mathrm{NH}_{4} \mathrm{NO}_{3} \cdot\left(\mathrm{NH}_{4}\right)_{2} \mathrm{SO}_{2}$ (B) during storage.

\subsection{Reactions of $\mathrm{AN}$ (ammonium nitrate) - $\mathrm{Mg}\left(\mathrm{NO}_{3}\right)_{2}$ in storage}

The $\mathrm{AN}-\mathrm{Mg}\left(\mathrm{NO}_{3}\right)_{2}$ (T3-1) sample can contain a large amount of $\mathrm{Mg}\left(\mathrm{NO}_{3}\right)_{2}$. If powdered $\mathrm{Mg}\left(\mathrm{NO}_{3}\right)_{2}$ is used, $\mathrm{AN}$ processes can end at low prilling temperatures and low inversion rates when the $\mathrm{AN}-\mathrm{Mg}\left(\mathrm{NO}_{3}\right)_{2}$ sample is kept at room temperature in a sealed tube for one year. The results of X-ray analyses are listed in Table 1 as T3-2. $\mathrm{Mg}\left(\mathrm{NO}_{3}\right)_{2}$ and $\mathrm{NH}_{4} \mathrm{NO}_{3}$ react and form $\mathrm{NH}_{4} \mathrm{NO}_{3} \cdot 2 \mathrm{Mg}\left(\mathrm{NO}_{3}\right)_{2}(\mathrm{C})$ double salt and $\mathrm{Mg}\left(\mathrm{NO}_{3}\right)_{2}$. 


$$
\mathrm{Mg}\left(\mathrm{NO}_{3}\right)_{2}+1.6\left(\mathrm{NH}_{4}, \mathrm{Mg}\right) \mathrm{NO}_{3}(75: 25) \rightarrow \mathrm{NH}_{4} \mathrm{NO}_{3}+0.2\left(\mathrm{NH}_{4} \mathrm{NO}_{3} \cdot 2 \mathrm{Mg}\left(\mathrm{NO}_{3}\right)_{2}\right)+\mathrm{Mg}\left(\mathrm{NO}_{3}\right)_{2}
$$

The AN-Mg( $\left(\mathrm{NO}_{3}\right)_{2}$ sample cakes less without degrading in storage. In these calculations, it was seen that the volume decreased by $0.9 \%$ by reaction (3). The sample contained a small amount of $2 \mathrm{NH}_{4} \mathrm{NO}_{3} \cdot\left(\mathrm{NH}_{4}\right)_{2} \mathrm{SO}_{2}(\mathrm{~B})$, and it was seen that this double salt was not in interacting with the sample under storage conditions.

\subsection{Preventing degradation and caking}

These methods have been applied to prevent degradation and caking:

(a) Amount of $2 \mathrm{NH}_{4} \mathrm{NO}_{3}\left(\mathrm{NH}_{4}\right)_{2} \mathrm{SO}_{2}$ (B) decreased by checking the rates of $\mathrm{NO}_{3} / \mathrm{SO}_{4}$ and $\mathrm{NH}_{4} / \mathrm{Mg}$.

(b) Degradation of $2 \mathrm{NH}_{4} \mathrm{NO}_{3} \cdot\left(\mathrm{NH}_{4}\right)_{2} \mathrm{SO}_{2}$ (B) double salt decreased by setting the rate of $\mathrm{Mg} /\left(\mathrm{NH}_{4}+\mathrm{Mg}\right.$ ) to less than 0.3 .

(c) Prilling and drying is realised at low temperatures to avoid degrading $2 \mathrm{NH}_{4} \mathrm{NO}_{3} \cdot\left(\mathrm{NH}_{4}\right)_{2} \mathrm{SO}_{2}$ (B) in $\mathrm{AN}$ samples that contain a large amount of $2 \mathrm{NH}_{4} \mathrm{NO}_{3} \cdot\left(\mathrm{NH}_{4}\right)_{2} \mathrm{SO}_{2}$ (B)

(d) The moisture rate in $\mathrm{AN}-\mathrm{Mg}\left(\mathrm{NO}_{3}\right)_{2}$ should be kept low because reactions proceed slowly in storage.

(e) For products like AN-Mg( $\left(\mathrm{NO}_{3}\right)_{2}$ that contain less $2 \mathrm{NH}_{4} \mathrm{NO}_{3} \cdot\left(\mathrm{NH}_{4}\right)_{2} \mathrm{SO}_{2}$ (B), high prilling temperature will help complete the reaction before the sample is stored.

\section{Discussion}

For prilled fertiliser and granular fertiliser, degradation and caking is the most important problem in storage conditions. In this research, $26 \% \mathrm{AN}, 33 \% \mathrm{AN}$, and $\mathrm{AN}-\mathrm{Mg}\left(\mathrm{NO}_{3}\right)_{2}$, the most commonly used fertilisers, were studied, and it was seen that in the final stored product depending on air moisture and temperature, any phase change in its structure caused caking. According to the amount of phase change, fertiliser prills adhere to each other, leading to more caking. As for the degradation problem, it is related to the increase in the unit volume of prilled fertilisers. If this increase is large, degradation will increase. Here, the AN- $\mathrm{Mg}\left(\mathrm{NO}_{3}\right)_{2}$ sample was manufactured by prilling after $\mathrm{Mg}\left(\mathrm{NO}_{3}\right)_{2}$ was sprayed with an ammonium nitrate solution. In these reactions, $10 \%$ unreacted $\mathrm{Mg}\left(\mathrm{NO}_{3}\right)_{2}$ was observed in the $\mathrm{AN}-\mathrm{Mg}\left(\mathrm{NO}_{3}\right)_{2}$ samples. This product was stored for one year and thereafter, $\mathrm{Mg}\left(\mathrm{NO}_{3}\right)_{2}$ in the product decreased by $4 \%$; as a result, it was observed that the amount of AN and $\mathrm{AN}-\mathrm{Mg}\left(\mathrm{NO}_{3}\right)_{2}$ double salt increased. At this point, caking was observed in the product. Therefore, for all samples, reactions occuring on prilling and cooling condition must be complete, because this will prevent the formation of a new phase in the product. Therefore, decreasing the size of $\mathrm{Mg}\left(\mathrm{NO}_{3}\right)_{2}$ granules, which are used in the reaction, is essential to complete the reaction.

Prilling is completed at $100{ }^{\circ} \mathrm{C}$ and products can be stored at $80{ }^{\circ} \mathrm{C}$. Fertilisers stored at high and low temperatures differ from each other as shown in Figure 6. The phases resulting from temperature differences are also shown in Figure 6. Due to the temperature differences, the probable reaction that forms between prills reduces the storage life. The most important chemical compound that causes caking is $2 \mathrm{NH}_{4} \mathrm{NO}_{3} \cdot\left(\mathrm{NH}_{4}\right)_{2} \mathrm{SO}_{2}(\mathrm{~B})$ double salt that forms by the reaction between $\mathrm{AN}$ and $\mathrm{H}_{2} \mathrm{SO}_{4}$. In particular, $26 \% \mathrm{AN}$ in the $26 \% \mathrm{AN} / 80$ product shows that a new phase forms during prilling and drying. Similarly, a new phase forms in the product during prilling and drying at $100{ }^{\circ} \mathrm{C}$ as well. After prilling and drying, when cooling the product to room temperature, thermal changes and volume changes occur according to the composition of the double salts formed during storage. This results in caking and the degradation problem.

In this study, it could be seen that $1 \%$ moisture destroyed form III of AN that forms by the reaction between $\mathrm{NO}_{3}$ and $\mathrm{SO}_{4}$ (Figure 7).

Another phenomenon related to the caking problem is plasticity. Plasticity occurs when the rate between the amounts of solid and liquid phases and melting point of AN are high (Brusset, Leveau, Spinat, Trani \& Verollet, 2002, pp.3).

It can be seen in Figure 7 that Mg stabilises form III of AN. Even if there is no moisture, form III (orthorhombic) of AN exists in high-temperature environments. Therefore, the existence of $\mathrm{Mg}, \mathrm{SO}_{4}$ and moisture are closely related to form III (orthorhombic). Another problem related to plasticity is the melting of the $\mathrm{AN}-\mathrm{Mg}\left(\mathrm{NO}_{3}\right)_{2}$ system at low temperature $\left(155^{\circ} \mathrm{C}\right)$. However, this is possible with $10 \%$ of $\mathrm{Mg}\left(\mathrm{NO}_{3}\right)_{2}$.

It has been shown in Figure 2 that the phases form in products between $50{ }^{\circ} \mathrm{C}$ and $100{ }^{\circ} \mathrm{C}$. This indicates the content of the product that forms during prilling, drying, and storage. The phase changes at room temperature are shown in Figure 3. As seen in the Figure 3, large volume differences between the phases causes caking. Therefore, if the formation of $2 \mathrm{NH}_{4} \mathrm{NO}_{3} \cdot\left(\mathrm{NH}_{4}\right)_{2} \mathrm{SO}_{2}$ (B) is prevented to form by the abovementioned methods, caking and degradation problems can be solved. 


\section{Conclusion}

At first glance, this research about nitrogenous fertilisers indicates that solutions to the caking and degradation problems cannot be generalised for all fertilisers. This is because this problem is not dependent only on formulation differences, but also on the process that is used and moisture differences in the contents. We would like to emphasise that the increase in volume that occurs during the reaction between $\mathrm{NO}_{3}$ and $\mathrm{SO}_{4}$ forms a $2 \mathrm{NH}_{4} \mathrm{NO}_{3} \cdot\left(\mathrm{NH}_{4}\right)_{2} \mathrm{SO}_{2}$ (B) double salt. Caking and degradation problems have been derived from this formulation.

\section{Acknowledgements}

Ahmet Ozan Gezeman is thankful to his elder sister "Aysun Gezerman Dilmen” for her inspiration.

\section{References}

Ando, J., \& Sai, G. (1970). Kogyo Kagaku Zaashi, Tokyo 73, 2614.

Ando, J., Miyamura, T., \& Akiyama, T. (1967). Crystallographic Properties of Fertiliser Compounds. Tennessee Valley Authory (May, 1967).

Ando, J., Siegal, J. P., \& Jordan, J.E. (1965). Journal of Agr. Food Chem. 13, 186.

Brusset, Leveau, Spinat, Trani, \& Verollet. (2002). Le Nitrate D'ammonium. [Online] Available: www.ensiacet.fr/web_a7/web_travail/web_a7/ensia7_fr/formation/dossier_a7/nitrate_d_ammonium.pdf (February, 2002).

Coats, R.V., \& Woodard, G.D. (1965). J. Chem. Soc. Eng, 2135.

Levin, E.M. (1969). Phase Diagram for Ceramists. Supplement, 264.

Theoret, A., \& Sandorfy. (1963). Infrared Spectra and Crystalline Phase Transitions of Ammonium Nitrate. [Online] Available: http://article.pubs.nrc-cnrc.gc.ca/RPAS/rpv?hm=HInit\&journal=cjc\&volume=42\&afpf=v64-009.pdf.

Yanagi, T. (1965). Journal of Phys. Soc., Japan, 20, 1351.

Table 1. Compounds Present Fertiliser (\%)

\begin{tabular}{|c|c|c|c|c|c|c|c|c|}
\hline & \multicolumn{3}{|c|}{$26 \%$ AN (T1) } & \multicolumn{3}{c|}{$33 \%$ AN(T2) } & \multicolumn{2}{c|}{$\begin{array}{c}35 \% \text { AN- } \\
\mathrm{Mg}_{(}\left(\mathrm{NO}_{3}\right)_{2}(\mathrm{~T} 3)\end{array}$} \\
\hline Compounds & $\mathrm{T} 1$ & $\mathrm{~T} 1 / 80$ & $\mathrm{~T} / 100$ & $\mathrm{~T} 2$ & $\mathrm{~T} 2 / 80$ & $\mathrm{~T} 2 / 100$ & $\mathrm{~T} 3-1$ & $\mathrm{~T} 3-2$ \\
\hline $\mathrm{III}-\left(\mathrm{NH}{ }_{4}, \mathrm{Mg}\right) \mathrm{NO}_{3}$ & $10(75: 25)$ & $13(75: 25)$ & $10(75: 25)$ & 0 & 0 & 0 & $22(75: 25)$ & $11(75: 25)$ \\
\hline $\mathrm{Mg}\left(\mathrm{NO}_{3}\right)_{2}$ & 0 & 0 & 0 & 3 & 3 & 0 & 3 & 10 \\
\hline $\left.\mathrm{NH}_{4} \mathrm{NO}_{3} \cdot 2 \mathrm{Mg}_{(} \mathrm{NO}_{3}\right)_{2}$ & 13 & 14 & 16 & 0 & 6 & 13 & 10 & 15 \\
\hline$\left(\mathrm{NH}_{4}, \mathrm{Mg}\right)_{4}\left(\mathrm{NO}_{3}\right)_{2} \mathrm{SO}_{4}$ & $39(75: 25)$ & $32(75: 25)$ & $20(75: 25)$ & $23(60: 40)$ & $12(60: 40)$ & $5(60: 40)$ & $5(70: 30)$ & $6(60: 40)$ \\
\hline$\left(\mathrm{NH}_{4}, \mathrm{Mg}\right)_{2} \mathrm{SO}_{4}$ & 0 & $3(75: 25)$ & $8(75: 25)$ & $13(30: 70)$ & $20(40: 60)$ & $23(50: 50)$ & $1(30: 70)$ & 0 \\
\hline
\end{tabular}

Numbers between brackets indicate $\mathrm{NH}_{4}: \mathrm{Mg}$ ratio of solid solutions.

Table 2. Heat of Formation of Double Salts and Solid Solutions from Simple Salts $\left(25^{\circ} \mathrm{C}\right)$

\begin{tabular}{|c|c|c|}
\hline Compounds & $\Delta \mathrm{H}(\mathrm{kcal} / \mathrm{mol})$ & $\Delta \mathrm{H}(\mathrm{cal} / \mathrm{g})$ \\
\hline $3 \mathrm{NH}_{4} \mathrm{NO}_{3}\left(\mathrm{NH}_{4}\right)_{2} \mathrm{SO}_{4}$ & 1.64 & 4.4 \\
\hline$\left(\mathrm{NH}_{4}, \mathrm{Mg}\right)_{4}\left(\mathrm{NO}_{3}\right)_{2} \mathrm{SO}_{4}(100: 0)$ & 0.75 & 2.2 \\
\hline$\left(\mathrm{NH}_{4}, \mathrm{Mg}\right)_{4}\left(\mathrm{NO}_{3}\right)_{2} \mathrm{SO}_{4}(75: 25)$ & 1.75 & 6.2 \\
\hline$\left(\mathrm{NH}_{4}, \mathrm{Mg}\right)_{4}\left(\mathrm{NO}_{3}\right)_{2} \mathrm{SO}_{4}(65: 35)$ & 2.73 & 8.5 \\
\hline $\mathrm{NH}_{4} \mathrm{NO}_{3} \cdot 2 \mathrm{Mg}\left(\mathrm{NO}_{3}\right)_{2}$ & 2.42 & 8.6 \\
\hline$\left(\mathrm{NH}_{4}, \mathrm{Mg}\right)_{2} \mathrm{SO}_{4}(50: 50)$ & 0.65 & 4.2 \\
\hline $\mathrm{III}-\left(\mathrm{NH}_{4}, \mathrm{Mg}\right) \mathrm{NO}_{3}(75: 25)$ & 0.27 & 3.1 \\
\hline
\end{tabular}

Numbers between brackets indicate $\mathrm{NH}_{4}: \mathrm{Mg}$ ratio of solid solutions. 
Table 3. Density of Double Salts and Solid Solutions and Expansion on Their Formation

\begin{tabular}{|c|c|c|c|}
\hline Compounds & Density (M) & Density (N) & Expansion (\%) \\
\hline $3 \mathrm{NH}_{4} \mathrm{NO}_{3}\left(\mathrm{NH}_{4}\right)_{2} \mathrm{SO}_{4}$ & 1.702 & 1.759 & 3.35 \\
\hline$\left(\mathrm{NH}_{4}, \mathrm{Mg}\right)_{4}\left(\mathrm{NO}_{3}\right)_{2} \mathrm{SO}_{4}(100: 0)$ & 1.691 & 1.764 & 4.32 \\
\hline$\left(\mathrm{NH}_{4}, \mathrm{Mg}\right)_{4}\left(\mathrm{NO}_{3}\right)_{2} \mathrm{SO}_{4}(75: 25)$ & 1.833 & 1.874 & 2.24 \\
\hline$\left(\mathrm{NH}_{4}, \mathrm{Mg}\right)_{4}\left(\mathrm{NO}_{3}\right)_{2} \mathrm{SO}_{4}(65: 35)$ & 1.904 & 1.918 & 0.74 \\
\hline $\mathrm{NH}_{4} \mathrm{NO}_{3} \cdot 2 \mathrm{Mg}\left(\mathrm{NO}_{3}\right)_{2}$ & 1.918 & 2.000 & 4.28 \\
\hline$\left(\mathrm{NH}_{4}, \mathrm{Mg}\right)_{2} \mathrm{SO}_{4}(50: 50)$ & 2.171 & 2.205 & 1.57 \\
\hline $\mathrm{III}-\left(\mathrm{NH}_{4}, \mathrm{Mg}\right) \mathrm{NO}_{3}(75: 25)$ & 1.821 & 1.858 & 1.98 \\
\hline
\end{tabular}

Density of soluble salts and solid solutions $(\mathrm{g} / \mathrm{mL})$

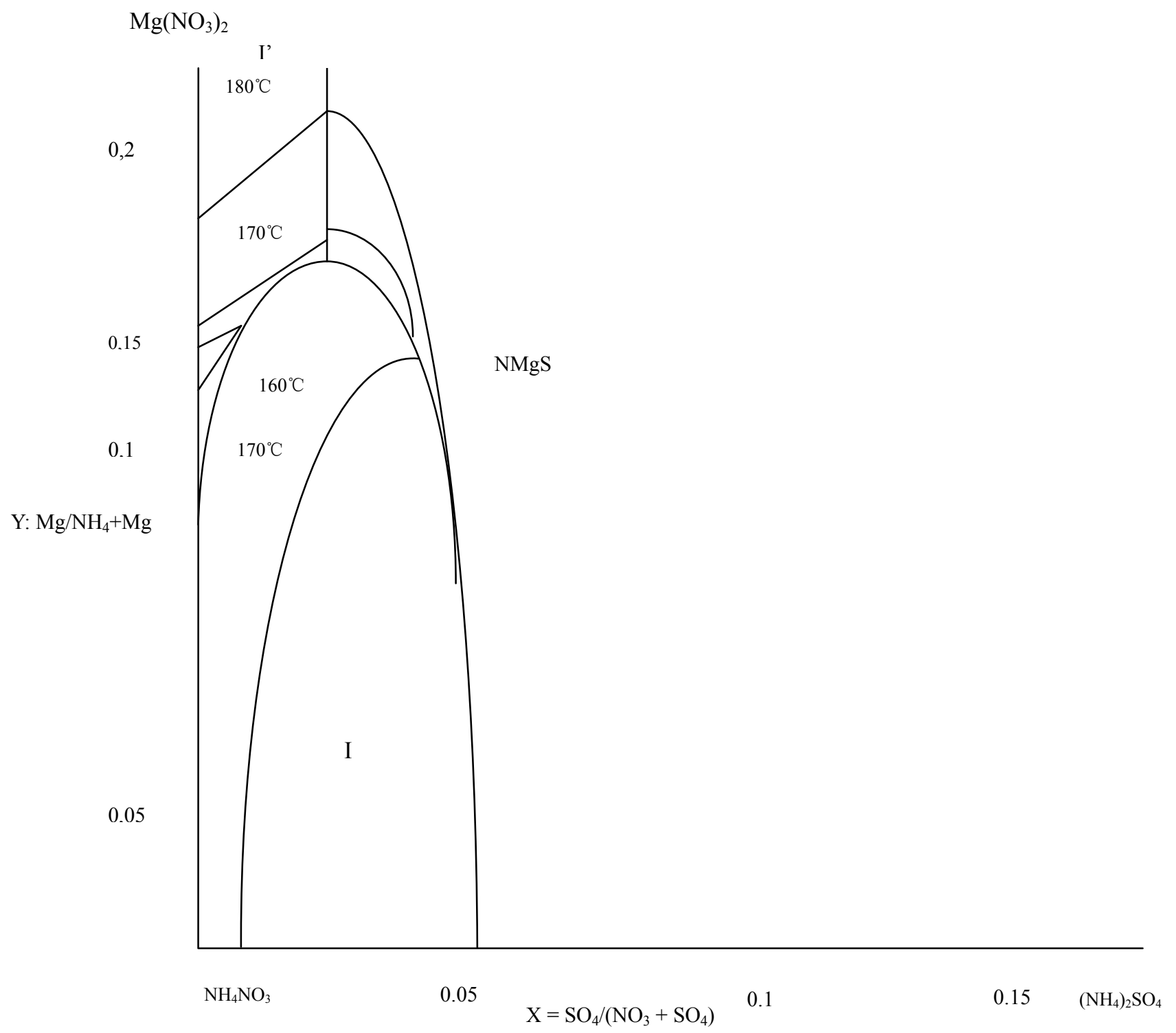

Figure 1. Phase Diagram of $\mathrm{NH}_{4} \mathrm{NO}_{3}-\mathrm{MgNO}_{3}-\mathrm{MgSO}_{4}-\left(\mathrm{NH}_{4}\right)_{2} \mathrm{SO}_{4}$ System

I': Form I Mg( $\left.\mathrm{NO}_{3}\right)_{2}$

I: Form I $\mathrm{NH}_{4} \mathrm{NO}_{3}$

$\mathrm{NMgS}:\left(\mathrm{NH}_{4}: \mathrm{Mg}\right) \mathrm{SO}_{4}$ 


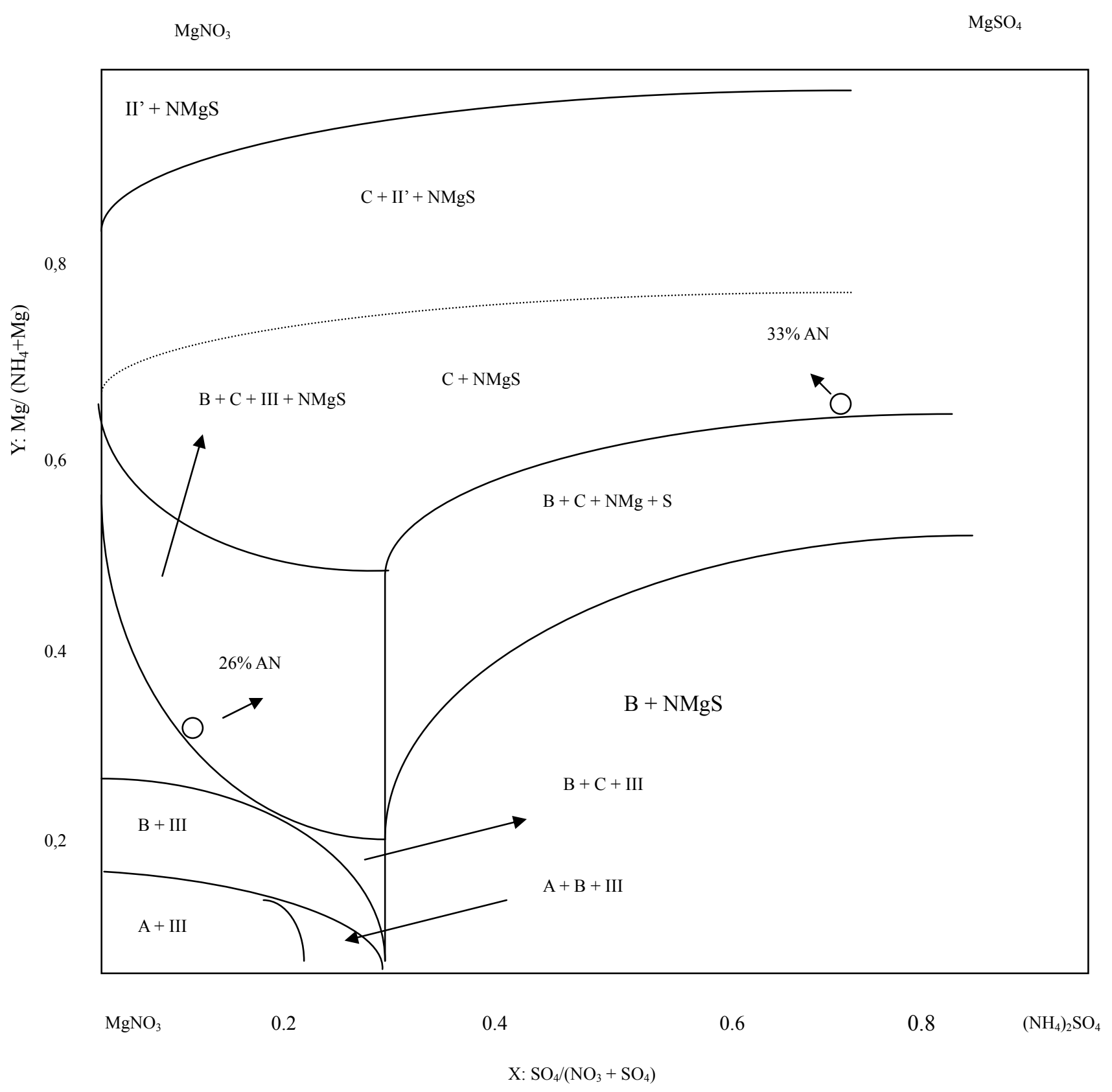

Figure 2. Compounds Immediately After Cooling To Room Temperature From $150{ }^{\circ} \mathrm{C}$ 


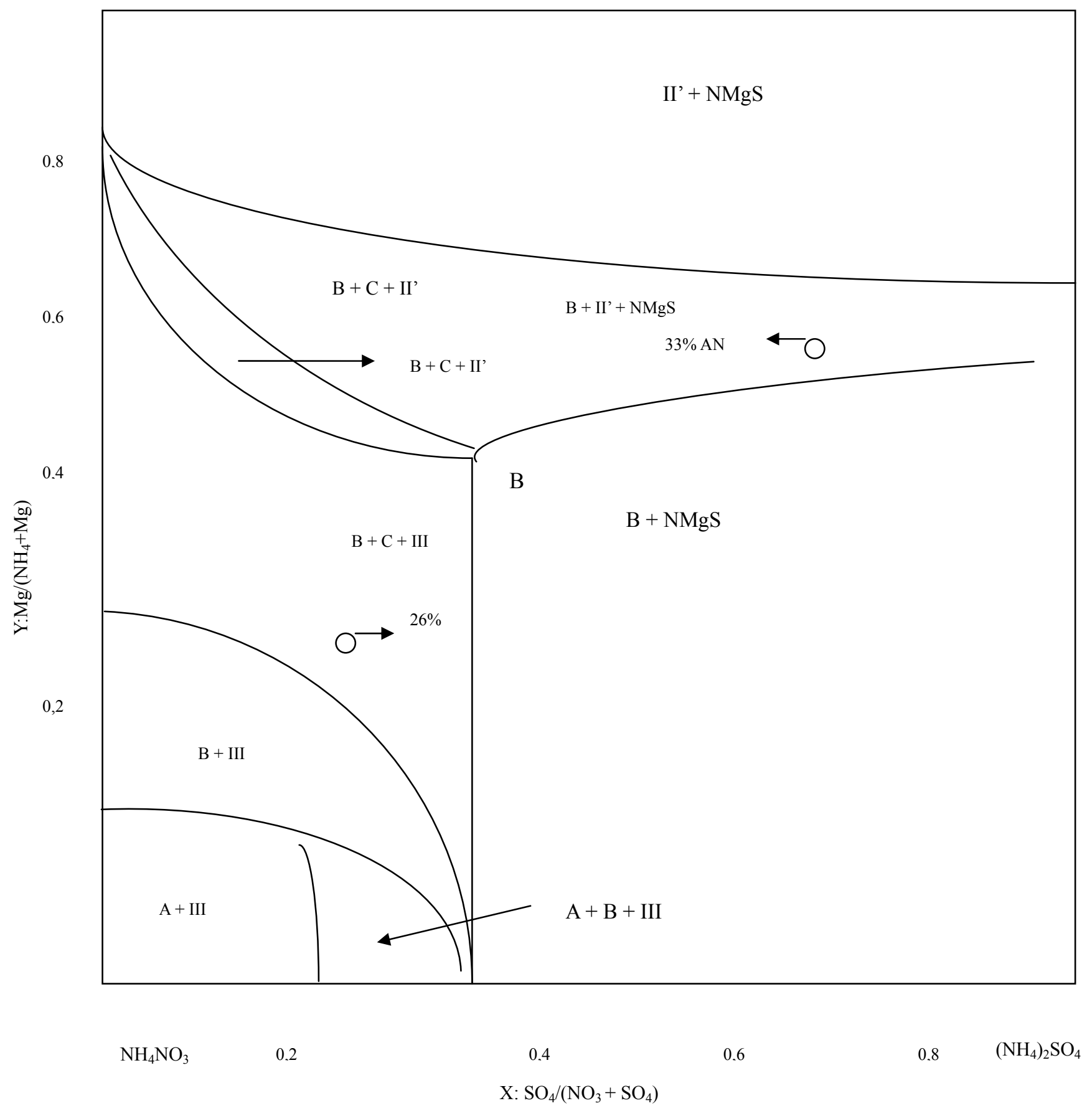

Figure 3. Compounds Stable at Room Temperature 


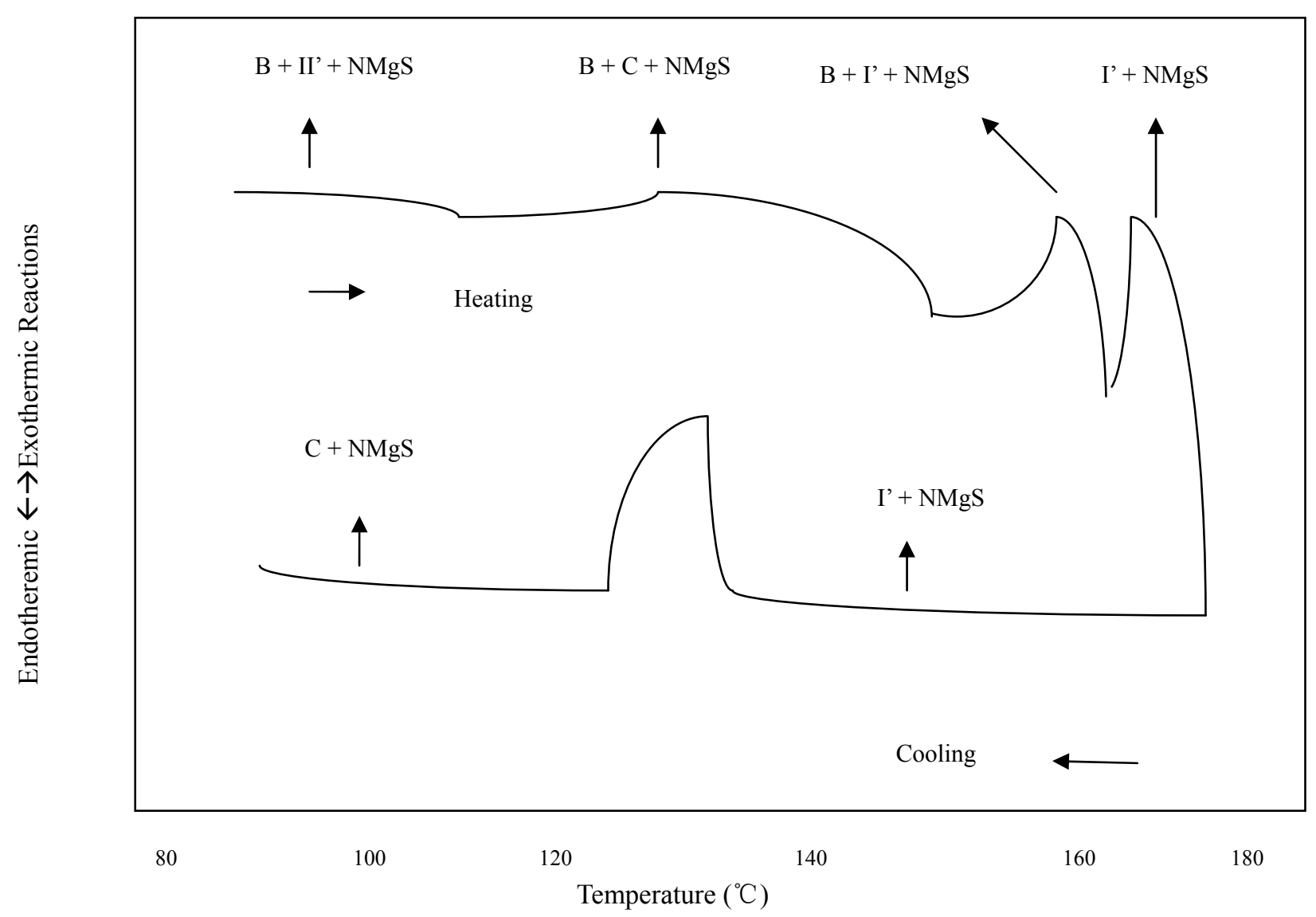

Figure 4. Differential Thermal Analysis Curve of A Sample X: 0.33, Y = 0.5

(I' means I - MgN)

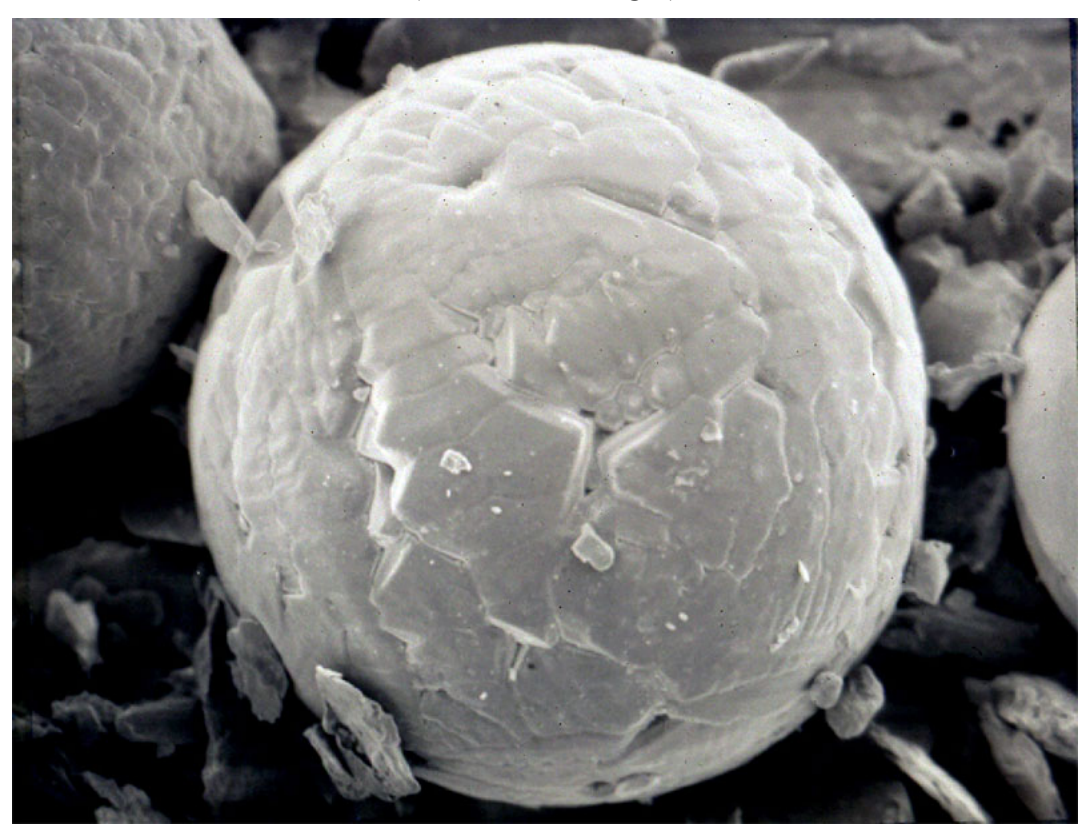

Figure 5. White Blister on the Surface Of Prilled AN 


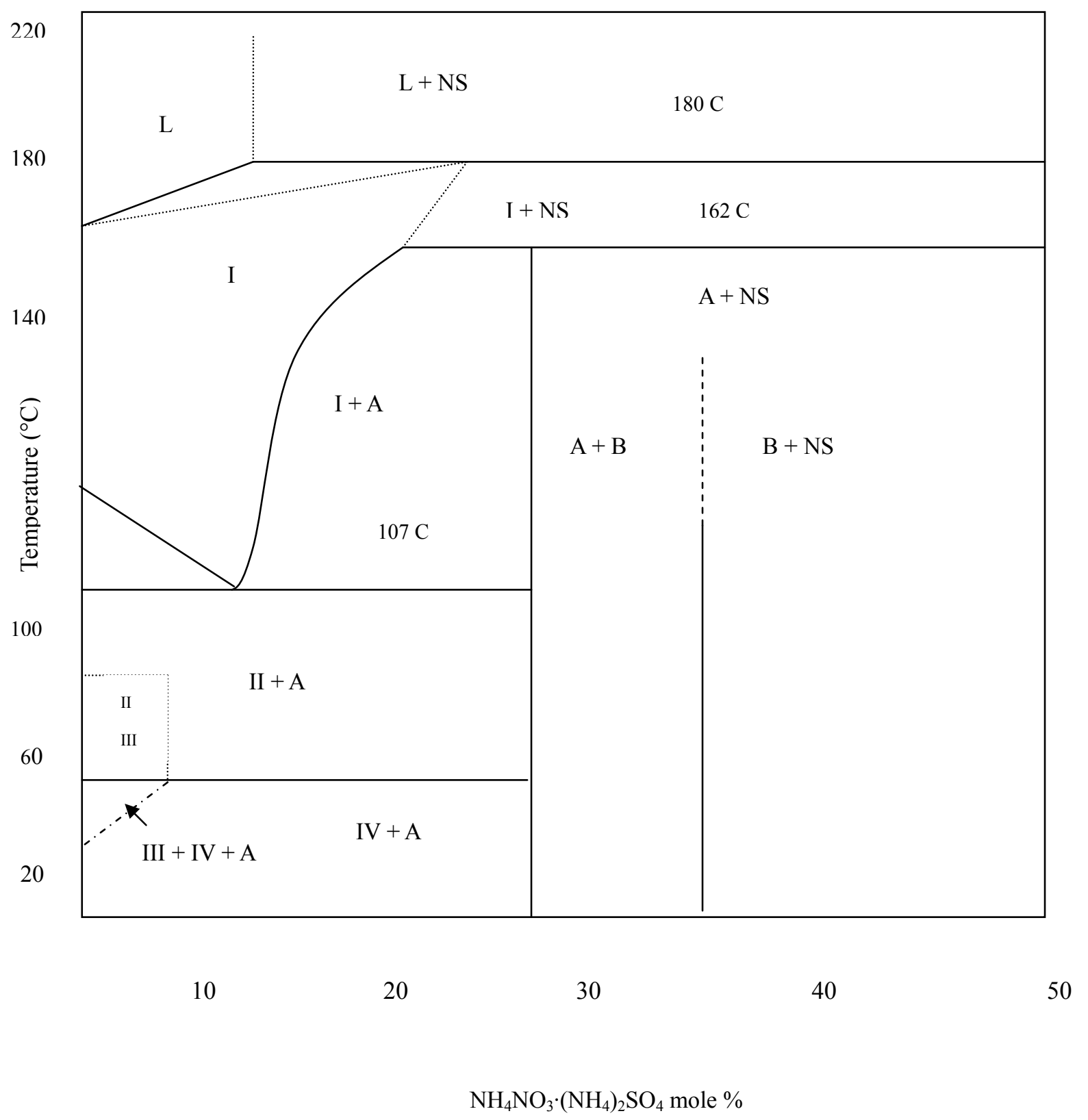

Figure 6. Phase Diagram of $\mathrm{NH}_{4} \mathrm{NO}_{3} \cdot\left(\mathrm{NH}_{4}\right)_{2} \mathrm{SO}_{4}$ System
I: Form I $\mathrm{NH}_{4} \mathrm{NO}_{3}$
A: $3 \mathrm{NH}_{4} \mathrm{NO}_{3} \cdot\left(\mathrm{NH}_{4}\right)_{2} \mathrm{SO}_{4}$
II: Form I $\mathrm{NH}_{4} \mathrm{NO}_{3}$
B: $2 \mathrm{NH}_{4} \mathrm{NO}_{3} \cdot\left(\mathrm{NH}_{4}\right)_{2} \mathrm{SO}_{4}$
III: Form III $\mathrm{NH}_{4} \mathrm{NO}_{3}$
L: Liquid
IV: Form III $\mathrm{NH}_{4} \mathrm{NO}_{3}$
NS: $\left(\mathrm{NH}_{4}\right)_{2} \mathrm{SO}_{4}$ 
220

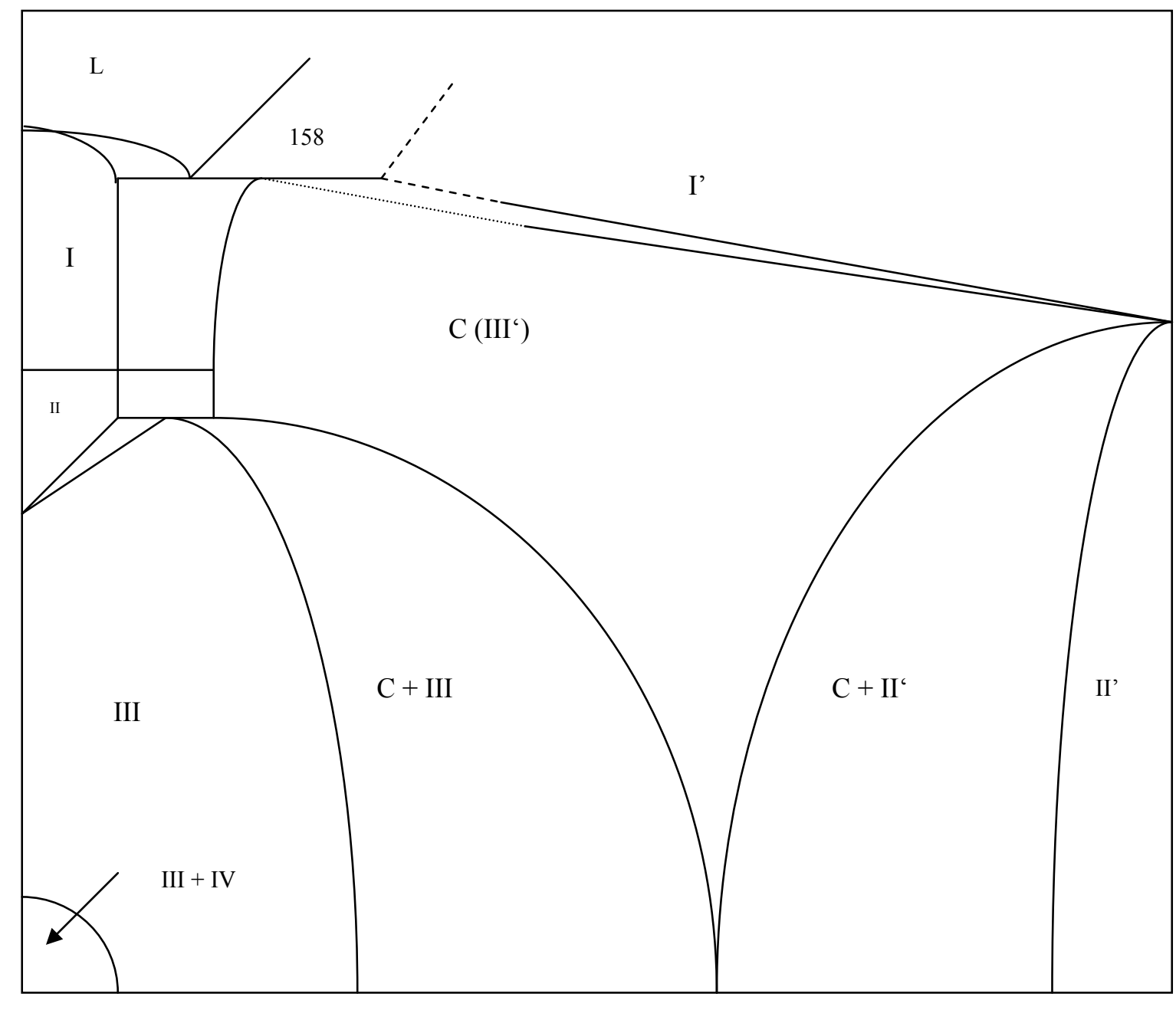

20

40

60

80

100

Figure 7. Phase Diagram of $\mathrm{NH}_{4} \mathrm{NO}_{3} \cdot \mathrm{Mg}\left(\mathrm{NO}_{3}\right)_{2}$ System

I': Form I $\mathrm{Mg}\left(\mathrm{NO}_{3}\right)_{2}$

II': Form II $\mathrm{Mg}\left(\mathrm{NO}_{3}\right)_{2}$

III': Form III $\mathrm{Mg}\left(\mathrm{NO}_{3}\right)_{2}$

C: $\mathrm{NH}_{4} \mathrm{NO}_{3} \cdot 2 \mathrm{Mg}\left(\mathrm{NO}_{3}\right)_{2}$ 